\title{
MOTIVASI BELAJAR BAHASA INGGRIS PADA SISWA MADRASAH ALIYAH DARUL MUTA'ALLIMIN SUGIHWARAS PATIANROWO NGANJUK
}

\author{
Tyas Alhim Mubarok \\ Program Studi Pendidikan Bahasa Inggris \\ Universitas Nahdlatul Ulama Blitar \\ tyasalhim@gmail.com
}

\begin{tabular}{l}
\hline Tersedia Online di \\
\hline http://www.jurnal.unublitar.ac.id/ \\
index.php/briliant \\
\hline \\
\hline Sejarah Artikel \\
\hline Diterima pada 15 Ferbruari 2019 \\
Disetuji pada 18 Februari 2019 \\
Dipublikasikan pada 20 Februari \\
2019 Hal. 118-124 \\
\hline
\end{tabular}

\begin{tabular}{l}
\hline Kata Kunci: \\
\hline $\begin{array}{l}\text { Motivasi belajar, intrinsik, } \\
\text { ekstrinsik, Bahasa Inggris }\end{array}$ \\
\hline DOI: \\
\hline http://dx.doi.org/10.28926/briliant \\
.v3i3.277 \\
\hline
\end{tabular}

\begin{abstract}
Abstrak: Penelitian ini bertujuan untuk mengetahui motivasi belajar bahasa Inggris baik motivasi intrinsik maupun ekstrinsik pada siswa Madrasah Aliyah Darul Muta'allimin Sugihwaras Patianrowo Nganjuk. Metode yang digunakan pada penelitian ini yaitu kuantitatif dengan sampel 30 siswa. Sedangkan untuk metode pengumpulan data dengan menggunakan angket yang berisi masingmasing 10 pertanyaan untuk motivasi intrinsik dan ekstrinsik. Hasil penelitian menunjukkan bahwa motivasi siswa dalam belajar bahasa Inggris yang paling dominan yaitu motivasi ekstrinsik dengan nilai 3,04. Sedangkan motivasi intrinsik lebih rendah yaitu 2,9 dari skala 4 . Dengan demikian dapat disimpulkan bahwa motivasi siswa dalam belajar bahasa Inggris diperoleh dari luar diri mereka sendiri yaitu seperti dari lingkungan dan teman. Sehingga guru perlu memberikan motivasi yang lebih agar keinginan siswa dalam belajar bahasa Inggris muncul dari dalam diri mereka sendiri sehingga mereka akan lebih bersemangat dan giat untuk mencapai keberhasilan dalam belajar bahasa Inggris.
\end{abstract}

\section{PENDAHULUAN}

Bahasa Inggris merupakan bahasa asing yang harus dipelajari oleh siswa di sekolah menengah atas (SMA) atau yang sederajat. Belajar bahasa asing membutuhkan usaha yang lebih karena bahasa tersebut jarang digunakan dalam komunikasi sehari-hari. Sehingga belajar bahasa asing membutuhkan waktu yang lama dan terus menerus agar dapat mencapai keberhasilan dalam setiap skill yang dipelajari seperti listening, speaking, reading, dan writing. Bagi mereka belajar bahasa Inggris tak semudah belajar bahasa pertama/kedua karena mereka baru mempelajari/mendengar bahasa tersebut di sekolah. Ada beberapa faktor yang mempengaruhi keberhasilan siswa dalam belajar bahasa asing diantaranya bakat (aptitude), motivasi (motivation), dan kesempatan (opportunity).

Penelitian ini fokus pada salah satu faktor tersebut, yaitu motivasi. Bagaimana motivasi siswa dalam belajar bahasa Inggris di Madrasah Aliyah Darul Muta'allimin Patianrowo Nganjuk. Motivasi merupakan suatu dorongan yang memicu seseorang berbuat sesuatu untuk mencapai suatu tujuan. Menurut KKBI motivasi adalah dorongan yang timbul pada diri seseorang secara sadar atau tidak sadar untuk melakukan suatu tindakan dengan tujuan tertentu. Seseorang yang memiliki motivasi kuat akan sungguh-sungguh dalam mendapatkan sesuatu yang diinginkannya. McDonough (1983, p.142) menyatakan bahwa "motivation of the students is one of the most important factors influencing their success or 
failure in learning the language". Menurutnya sukses tidaknya siswa dalam belajar bahasa tergantung pada motivasi individu masing-masing. Pernyataan itu didukung oleh Lifrieri (2005, p. 4) yang berpendapat bahwa ketika kita bertanya tentang faktor yang mempengaruhi level kesuksesan seseorang dalam melakukan sesuatu, termasuk belajar bahasa, maka salah satunya adalah motivasi.

Dalam pencapaian prestasi belajar, Motivasi belajar siswa memegang peranan yang sangat penting. Menurut Mc. Donald yang di kutip oleh Sardiman (2014) motivasi merupakan perubahan energi yang ada dalam diri seseorang yang ditandai dengan munculnya feeling dan didahului tanggapan terhadap adanya tujuan. Gardner (2006, p. 241) berpendapat bahwa siswa dengan yang memiliki motivasi yang tinggi akan melakukan hal (belajar) lebih baik dari pada siswa dengan motivasi rendah. Dengan adanya motivasi yang kuat pada individu (siswa) dapat membangkitkan semangat yang tinggi pula dalam belajar.

Motivasi dibagi menjadi dua jenis yaitu motivasi intrinsik dan motivasi ekstrinsik. Motivasi intrinsik adalah bentuk dorongan belajar yang datang dari dalam diri seseorang dan tidak perlu rangsangan dari luar, sedangkan motivasi ekstrinsik adalah dorongan belajar yang datangnya dari luar diri seseorang (Sri Hapsari: 2005, 74). Dari pengertian yang dikemukakan Mc. Donald ini mengandung tiga elemen penting yaitu (1) bahwa motivasi itu mengawali terjadinya perubahan energi pada diri setiap individu manusia, (2) motivasi ditandai dengan munculnya rasa dan afeksi seseorang, (3) motivasi akan dirangsang karena adanya tujuan.

Dari beberapa pendapat tersebut dapat disimpulkan bahwa motivasi adalah sesuatu yang menyebabkan terjadinya suatu perubahan dalam diri individu yang mempengaruhi gejala kejiwaan, perasaan, dan emosi untuk melakukan sesuatu yang didorong oleh adanya tujuan, kebutuhan atau keinginan. Menurut Thursan Hakim (2000) yang dikutip Winastwan Gora dan Sunarto (2010: 16), belajar adalah suatu proses perubahan perubahan didalam manusia, ditampakan dalam bentuk peningkatan kualitas dan kuantitas tingkah laku seperti peningkatan kecakapan, pengetahuan, sikap, kebiasaan, pemahaman, keterampilan, daya pikir dan lain-lain. Jadi dalam kegiatan belajar terjadinya adanya suatu usaha yang menghasilkan perubahan-perubahan itu dapat diamati secara langsung maupun tidak langsung.

Motivasi menjadi sesuatu yang sangat penting bagi siswa dalam kegiatan belajar. Kuat tidaknya motivasi siswa dalam belajar bahasa Inggris sangat mempengaruhi proses aktivitas belajar dalam kelas. Menurut Sardiman AM (2003 : 83) siswa yang memiliki motivasi kuat dalam belajar, memiliki ciri-ciri sebagai berikut:

1) Tekun menghadapi tugas (dapat belajar terus menerus dalam waktu yang lama, tidak pernah berhenti sebelum selesai).

2) Ulet menghadapi kesulitan (tidak mudah putus asa). Tidak memerlukan dorongan dari luar untuk berprestasi sebaik mungkin (tidak cepat puas dengan prestasi yang telah dicapai).

3) Mewujudkan minat terhadap bermacam-macam masalah untuk orang dewasa. (misalnya masalah pembangunan, agama, politik, ekonomi, keadilan, pemberantasan korupsi, penentangan terhadap setiap tindak kriminal, amoral dan sebagainya). 
4) Lebih senang bekerja mandiri

5) Cepat bosan pada tugas-tugas yang rutin (hal-hal yang bersifat mekanis, berulang-ulang begitu saja, sehingga kurang kreatif).

6) Dapat mempertahankan pendapatnya (kalau sudah yakin akan sesuatu)

7) Tidak mudah melepaskan hal yang diyakini itu

8) Senang mencari dan memecahkan masalah soal-soal

Apabila seorang siswa memiliki ciri-ciri tersebut berarti siswa tersebut memiliki motivasi belajar yang cukup kuat yang dibutuhkan dalam aktifitas belajarnya. Dengan demikian dapat disimpulkan bahwa siswa yang memiliki motivasi tinggi dalam belajar akan memiliki ciri-ciri sebagai berikut:

a. Keinginan mendalami materi

b. Ketekunan dalam mengerjakan tugas

c. Keinginan berprestasi

d. Keinginan untuk maju

Penelitian ini bertujuan untuk mengetahui seperapa besar motivasi siswa dalam belajar bahasa Inggris pada siswa MA Darul Muta'allimin Sugihwaras Patianrowo Kab. Nganjuk. Selain itu penelitian ini juga bertujuan untuk mengetahui motivasi apa yang paling dominan dimiliki siswa dalam belajar bahasa Inggris. Dengan demikian guru dapat memilih metode yang tepat yang mampu menciptakan situasi belajar mengajar yang dapat mendorong dan merangsang siswa agar lebih semangat, aktif, dan kreatif dalam belajar bahasa Inggris.

\section{METODE}

Penelitian ini menggunakan metode deskriptif kuantitatif. Data kuantitatif diperoleh dari perhitungan sederhana untuk mencari nilai rata-rata dari jawaban siswa terhadap pernyataan-pernyataan yang telah diberikan. Setelah itu dideskripsikan dalam bentuk uraian berdasarkan hasil yang didapat. Sampel pada penelitian ini yaitu ada 30 siswa yang terdiri dari kelas X, XI, dan XII. Metode pengambilan data diperoleh dari angket yang berisi sepuluh pertanyaan untuk motivasi intrinsik dan sepuluh pertanyaan untuk motivasi ekstrinsik. Dari masingmasing pernyataan terdapat 4 aspek untuk jawaban yaitu sangat setuju, setuju, tidak setuju, dan sangat tidak setuju. Sedangkan untuk penilaian, terdapat 1-4 skala yaitu sangat setuju 4, setuju 3, tidak setuju 2, sangat tidak setuju 1.

\section{PEMBAHASAN}

\section{Motivasi Intrinsik}

Motivasi intrinsik merupakan faktor dorongan yang berasal dari diri sisiwa sendiri. Motivasi ini sangat berpengaruh dalam pencapain keberhasilan belajar, termasuk dalam belajar bahasa Inggris. Apabila seorang siswa memiliki motivasi intrinsik yang kuat dan besar, mereka akan lebih sungguh-sungguh dan semangat dalam belajar meskipun banyak rintangan yang mereka hadapi.

Pada penelitian ini terdapat 4 faktor yaitu keinginan diri, kepuasan, kebiasaan baik, dan kesadaran. Faktor keinginan diri terdapat 4 pernyataan, sedangkan kepuasan, kebiasaan baik, dan kesadaran masing-masing terdapat 2 pernyataan. Sehingga total pertnyataan ada 10 untuk motivasi intrinsik yang 
dijawab oleh siswa. Masing-masing pernyataan untuk motivasi intrinsik dapat dilihat pada tabel berikut:

Tabel 1. Pernyataan Faktor Motivasi Intrinsik

\begin{tabular}{|c|c|c|c|c|c|}
\hline $\begin{array}{c}\text { Faktor } \\
\text { Intrinsik }\end{array}$ & No & Pernyataan & $\mathrm{N}$ & Total & Mean \\
\hline \multirow{4}{*}{$\begin{array}{c}\text { Keinginan } \\
\text { Diri }\end{array}$} & 1 & Saya sangat senang belajar bahasa Inggris & 30 & 86 & 2,87 \\
\hline & 2 & $\begin{array}{l}\text { Saya belajar bahasa Inggris di luar jam sekolah atas } \\
\text { keinginan saya sendiri }\end{array}$ & 30 & 71 & 2,37 \\
\hline & 3 & $\begin{array}{l}\text { Saya rajin belajar karena tidak ingin nilai bahasa Inggris } \\
\text { saya jelek }\end{array}$ & 30 & 92 & 3,07 \\
\hline & 4 & $\begin{array}{l}\text { Setiap ada pekerjaan rumah atau tugas saya selalu ingin } \\
\text { cepat-cepat mengerjakannya }\end{array}$ & 30 & 76 & 2,53 \\
\hline \multirow[b]{2}{*}{ Kepuasan } & 5 & Saya puas jika nilai bahasa Inggris saya baik & 30 & 105 & 3,5 \\
\hline & 6 & $\begin{array}{l}\text { Saya puas jika nilai tugas saya bagus, maka saya dengan } \\
\text { sungguh-sungguh mengerjakan tugas yang diberikan } \\
\text { oleh guru }\end{array}$ & 30 & 91 & 3,03 \\
\hline \multirow{2}{*}{$\begin{array}{l}\text { Kebiasaan } \\
\text { Baik }\end{array}$} & 7 & $\begin{array}{l}\text { Jika besok ada pelajaran bahasa Inggris, pada malam hari } \\
\text { saya selalu mempelajari materi bahasa Inggris di rumah } \\
\text { terlebih dahulu }\end{array}$ & 30 & 71 & 2,37 \\
\hline & 8 & $\begin{array}{l}\text { Saya tidak pernah bolos pada jam pelajaran bahasa } \\
\text { Inggris }\end{array}$ & 30 & 94 & 3,13 \\
\hline \multirow[b]{2}{*}{ Kesadaran } & 9 & $\begin{array}{l}\text { Tanpa disuruh saya mengerjakan tugas bahasa Inggris } \\
\text { yang telah diberikan oleh guru }\end{array}$ & 30 & 81 & 2,7 \\
\hline & 10 & $\begin{array}{l}\text { Tanpa disuruh saya selalu mencatat hal-hal yang } \\
\text { penting disaat pelajaran bahasa Inggris sedang } \\
\text { berlangsung }\end{array}$ & 30 & 91 & 3,03 \\
\hline
\end{tabular}

Dari tabel diatas dapat diketahui bahwa dari 10 pernyataan untuk motivasi intrinsik, siswa kebanyakan dominan pada pernyataan "Saya puas jika nilai bahasa Inggris saya baik" dengan nilai rata-rata 3,5 dari skala 4. Sehingga dapat disimpulkan bahwa kebanyakan siswa setuju dan puas jika nilai bahasa Inggris mereka baik. Sedangkan pernyataan yang memperoleh nilai terendah yaitu "Saya belajar bahasa Inggris di luar jam sekolah atas keinginan saya sendiri" dan "Jika besok ada pelajaran bahasa Inggris, pada malam hari saya selalu mempelajari materi bahasa Inggris di rumah terlebih dahulu " dengan nilai 2,37. Dari nilai tersebut dapat diketahui bahwa siswa kebanyakan tidak belajar bahasa Inggris di luar jam sekolah karena keinginan mereka sendiri dan juga mereka kebanyakan tidak belajar sebelumnya jika besok ada pelajaran bahasa Inggris. Ini menunjukkan bahwa mereka kurang sekali minat dalam belajar bahasa Inggris.

Tabel 2. Rata-rata faktor intrinsik

\begin{tabular}{|c|c|c|c|}
\hline No & Faktor Intrinsik & Sum & Mean \\
\hline 1 & Keinginan diri & 325 & 2,71 \\
\hline 2 & Kepuasan & 196 & 3,27 \\
\hline 3 & Kebiasaan baik & 165 & 2,75 \\
\hline 4 & Kesadaran & 172 & 2,87 \\
\hline & Total & 858 & 11,6 \\
\hline
\end{tabular}


Tabel diatas menunujukkan bahwa dari 4 faktor intrinsik yang paling dominan dimiliki siswa dalam belajar bahasa Inggris yaitu kepuasan dengan nilai rata-rata 3,27. Kemudian faktor yang paling dominan selanjutnya yaitu kesadaran dengan nilai 2,87 dan kebiasaan baik dengan nilai 2,27. Sedangkan faktor yang paling rendah dimiliki siswa yaitu keinginan diri dengan nilai 2,71. Sehingga dapat ditarik kesimpulan bahwa keinginan dari diri mereka dalam belajar bahasa Inggris sangat rendah. Hal tersebut mempengaruhi kebiasaan mereka dalam belajar seperti tidur di kelas, tidak mendengarkan guru, membolos, dan tidak mengerjakan tugas.

\section{Motivasi Ekstrinsik}

Motivasi ekstrinsik merupakan motivasi yang berasal dari luar individu seperti lingkungan maupun teman. Motivasi ini biasanya dijadikan alat untuk mencapai tujuan tertentu. Misalnya mereka akan belajar bahasa Inggris agar mendapat pujian maupun penghargaan dari orang lain. Karena faktor pendorong mereka belajar bahasa bukan dari dalam individu, untuk mencapai keberhasilan dalam belajar bahasa juga sulit dan kurang optimal. Ada 6 faktor pada motivasi ekstrinsik yaitu pujian, nasehat, semangat, hadiah, hukuman, dan meniru sesuatu. Dari faktor-faktor tersebut terdapat 10 pernyataan juga untuk motivasi intrinsik seperti dalam tabel dibawah ini:

Tabel 3. Pernyataan faktor motivasi ekstrinsik

\begin{tabular}{|c|c|c|c|c|c|}
\hline $\begin{array}{c}\text { Faktor } \\
\text { Ekstrinsik }\end{array}$ & No & Pernyataan & $\mathrm{N}$ & Total & Mean \\
\hline \multirow{2}{*}{ Pujian } & 1 & $\begin{array}{l}\text { Guru memuji saya jika nilai tugas bahasa Inggris saya } \\
\text { baik }\end{array}$ & 30 & 89 & 2,97 \\
\hline & 2 & $\begin{array}{l}\text { Saya mendapat pujian dari orang tua, jika } \\
\text { saya mendapat nilai bahasa Inggris yang baik }\end{array}$ & 30 & 79 & 2,67 \\
\hline \multirow[t]{2}{*}{ Nasehat } & 3 & $\begin{array}{l}\text { Orang tua saya menasehati saya agar tidak pernah } \\
\text { bolos pada jam pelajaran }\end{array}$ & 30 & 106 & 3,53 \\
\hline & 4 & Teman-teman menasehati saya untuk rajin belajar & 30 & 82 & 2,73 \\
\hline \multirow{2}{*}{ Semangat } & 5 & $\begin{array}{l}\text { Guru saya memberikan semangat kepada saya } \\
\text { untuk lebih giat lagi dalam belajar }\end{array}$ & 30 & 107 & 3,57 \\
\hline & 6 & $\begin{array}{l}\text { Orang tua saya memberikan semangat agar tidak } \\
\text { mudah menyerah dalam menuntut ilmu }\end{array}$ & 30 & 111 & 3,7 \\
\hline Hadiah & 7 & $\begin{array}{l}\text { Saya lebih bersemangat lagi untuk berprestasi } \\
\text { jika mendapat hadiah dari orang tua saya }\end{array}$ & 30 & 88 & 2,93 \\
\hline Hukuman & 8 & $\begin{array}{l}\text { Guru memberi hukuman kepada siswa yang bolos } \\
\text { pada jam pelajaran, sehingga para siswa tidak ada } \\
\text { yang ingin membolos }\end{array}$ & 30 & 80 & 2,67 \\
\hline \multirow{2}{*}{$\begin{array}{l}\text { Meniru } \\
\text { sesuatu }\end{array}$} & 9 & $\begin{array}{l}\text { Apabila saya melihat teman-teman sedang asik } \\
\text { belajar, maka muncul keinginan saya untuk ikut } \\
\text { belajar }\end{array}$ & 30 & 91 & 3,03 \\
\hline & 10 & $\begin{array}{l}\text { Apabila teman saya nilai tugasnya bagus, maka } \\
\text { muncul keinginan saya untuk ikut mendapatkan nilai } \\
\text { tugas yang bagus }\end{array}$ & 30 & 95 & 3,17 \\
\hline
\end{tabular}


Berdasarkan tabel diatas diketahui bahwa dari 10 pernyataan, yang mendapatkan nilai tertinggi yaitu "Orang tua saya memberikan semangat agar tidak mudah menyerah dalam menuntut ilmu" dengan nilai 3,7. Ini menunjukkan bahwa mereka akan lebih giat belajar apabila dinasehati oleh orang tua. Sedangkan pernyataan yang mendapatkan nilai terendah yaitu "Saya mendapat pujian dari orang tua, jika saya mendapat nilai bahasa Inggris yang baik" dan "Guru memberi hukuman kepada siswa yang bolos pada jam pelajaran, sehingga para siswa tidak ada yang ingin membolos" dengan nilai 2,67. Dari data tersebut dapat disimpulkan bahwa siswa kurang setuju apabila mereka belajar bahasa Inggris karena mendapatkan pujian dari orang tua dan mereka kurang setuju kalau mereka tidak membolos karena mendapatkan hukuman.

Tabel 4. Rata-rata faktor ekstrinsik

\begin{tabular}{|c|c|c|c|}
\hline No & Faktor Ekstrinsik & Sum & Mean \\
\hline 1 & Pujian & 168 & 2,8 \\
\hline 2 & Nasehat & 188 & 3,13 \\
\hline 3 & Semangat & 218 & 3,64 \\
\hline 4 & Hadiah & 88 & 2,93 \\
\hline 5 & Hukuman & 80 & 2,67 \\
\hline 6 & Meniru sesuatu & 186 & 3,1 \\
\hline & Total & 928 & 18,26 \\
\hline
\end{tabular}

Faktor-faktor yang menjadi motivasi ekstrinsik atau dorongan dari luar yaitu pujian, nasehat, semangat, hadiah, hukuman, dan meniru sesuatu. Diantara faktor tersebut faktor yang paling dominan yaitu faktor semangat yang diberikan oleh orang tua/guru pada individu tersebut. Mereka akan giat belajar apabila terus disemangati oleh orang-orang terdekatnya. Sehingga niat mereka belajar bahasa Inggris kurang tulus dari hati setiap invidu. Hal ini menyebabkan mereka bisa saja dengan mudah tidak semangat lagi dalam belajar bahasa Inggris apabila tidak disemangati. Oleh sebab itu, keberhasilan mereka dalam belajar bahasa Inggris akan sulit dicapai. Dari penelitian dan pembahasan di atas dapat disimpulkan bahwa dari kedua motivasi tersebut, yaitu intrinsik dan ekstrinsik yang paling dominan dimiliki siswa Darul Muta'allimin Sugihwaras Patianrowo Nganjuk yaitu motivasi ekstrinsik. Seperti ditunjukkan pada tabel berikut:

Tabel 5. Perbandingan nilai rata-rata motivasi intrinsik dan ekstrinsik

\begin{tabular}{|c|c|c|c|l|l|}
\hline No & Motivasi & N & Jumlah Faktor & Total & Mean \\
\hline 1 & Intrinsik & 30 & 4 & 11,6 & 2,9 \\
\hline 2 & Ekstrinsik & 30 & 6 & 18,26 & 3,04 \\
\hline
\end{tabular}

Dari data di atas, dapat kita lihat bahwa motivasi intrinsik siswa lebih rendah dari pada motivasi ekstrinsik dalam belajar bahasa Inggris. Hal ini dikarenakan siswa lebih mendapatkan dorongan dalam belajar bahasa Inggris karena faktor luar seperti mereka akan mau belajar bahasa Inggris karena bahasa Inggris dijadikan salah satu mata pelajaran yang ada di sekolah mereka dan menjadi salah satu mata pelajaran untuk ujian nasional. Sehingga kurangnya kesadaran diri dalam belajar bahasa Inggris juga mempengaruhi keberhasilan mereka dalam belajar. Penelitian ini sejalan dengan penelitian lain dari (Al- 
Tamimi, A and Shuib, 2009) yang berpendapat bahwa kebanyakan siswa pada saat ini memiliki sikap negatif terhadap pentingnya menggunakan bahasa Inggris karena menganggap bahasa Inggris hanya sebagai bahasa asing yang jarang digunakan.

\section{KESIMPULAN}

Motivasi merupakan salah satu faktor pendorong untuk mencapai keberhasilan dalam belajar bahasa Inggris. Berdasarkan hasil dan pembahasan dari penelitian ini, dapat disimpulkan bahwa siswa Madrasah Aliyah Darul Muta'allimin memiliki motivasi ekstrinsik lebih tinggi dari pada motivasi intrinsik dalam belajar bahasa Inggris. Hal ini menunjukkan bahwa keinginan mereka belajar bahasa Inggris masih belum murni dari diri individu melainkan masih banyak dipengaruhi oleh faktor luar seperti lingkungan dan teman. Oleh karena itu, perlu perlakuan khusus dan tindakan lebih untuk memotivasi siswa agar lebih semangat dan giat dalam belajar.

\section{SARAN}

Belajar bahasa Inggris tentu membutuhkan usaha yang lebih. Terlebih harus ada niat yang kuat dari dalam diri individu agar tercapai keberhasilan dalam belajar bahasa Inggris. Untuk itu guru harus menyiapkan metode maupun strategi yang tepat untuk membangkitkan keinginan dan kesadaran siswa dalam belajar bahasa ingggris. Guru harus bisa menciptakan suasana kelas yang tepat, nyaman, dan kondusif agar siswa lebih semangat dalam belajar sehingga menganggap belajar bahasa Inggris itu mudah dan menyenangkan. Sehingga prestasi dan tujuan dalam belajar bahasa Inggris dapat tercapai dengan maksimal.

\section{DAFTAR RUJUKAN}

Al-Tamimi, Atef and Shuib, Munir. 2009. Motivation And Attitudes Towards Learning English: A Study Of Petroleum Engineering Undergraduates At Hadhramout University Of Sciences And Technology. GEMA Online Journal of Language Studies Volume 9(2) 2009

Danar, Vreedy Frans. 2012. Hubungan Antara Motivasi Belajar Intrinsik Dan Ekstrinsik Siswa Dengan Prestasi Belajar Siswa Kelas X Kompetensi Keahlian Teknik Audio Video SMK Ma'arif 1 Wates. Skripsi. Universitas Negeri Yogyakarta

Gardner, R. (2006). The socio-educational model of second language acquisition: a research paradigm. EUROSLA Yearbook, 6, 237-260.

McDonough, S. (1983). Psychology In Foreign Language Teaching. George Allen \& Unwin: London

Lifrieri, V. (2005). A sociological perspective on motivation to learn EFL: The case of escuelas plurilinguies in Argentina. M.A thesis, University of Pittsburgh.

Thursan, Hakim, 2008. Belajar Secara Evektif. Jakarta: Pustaka Pembangunan Swadana Nusantara

Sardiman, A. 2014. Interaksi Dan Motivasi Belajar Mengajar. Jakarta: PT Raja grafindo persada

Winastwan Gora, Sunarto. 2010. Pakematik: Srategi Pembelajara Inovatif Berbasis TIK. Elex Media Komputindo 